\title{
FACTORS AFFECTING THE USE OF FAMILY PLANNING IMPLANT AT WAE MBELENG COMMUNITY HEALTH CENTER, MANGGARAI, EAST NUSA TENGGARA
}

\author{
Dionesia Octaviani Laput, Stefanus P. Manongga, Muntasir
}

\begin{abstract}
Masters Program in Public Health, Faculty of Public Health, Universitas Nusa Cendana Study Program in Diploma-III, Faculty of Health Science and Agriculture, Universitas Katolik Indonesia St.Paulus Ruteng
\end{abstract}

\begin{abstract}
Background: The paradigm of the Indonesian national family planning (FP) program has changed from realizing the "Norms of Happy and Prosperous Small Families into a vision to realize "Quality Families in 2015". FP program is one of the popular population policies in the field of birth (fertility). The FP program aims to meet the demand for quality reproductive health services and control the birth rate. This program will create good quality of small families and improve the quality of the population. This study aimed to determine the factors affecting the use of family planning implant in Wae Mbeleng community health center, Manggarai, East Nusa Tenggara.

Subjects and Method: This was a cross-sectional study conducted at Wae Mbeleng community health center, Manggarai, East Nusa Tenggara, from January to March 2019. A total sample of 392 women in reproductive age was selected at random for this study. The dependent variable was the use of FP implant. The independent variables were age, information from a health worker, and husband support. The data were collected by questionnaire and analyzed using a multiple logistic regression.

Results: A total of $0.9 \%$ of women in reproductive age was using implant at Wae Mbeleng community health center. The use of FP implant were associated with age $(\mathrm{OR}=0.19 ; 95 \% \mathrm{CI}=0.05$ to $0.60 ; \mathrm{p}=0.005)$, high education $(\mathrm{OR}=8.93 ; 95 \% \mathrm{CI}=2.73$ to 24.73 ; $\mathrm{p}<0.001)$, poor knowledge $(\mathrm{OR}=0.02 ; 95 \% \mathrm{CI}=0.01$ to $0.02 ; \mathrm{p}<0.001)$, information from health worker $(\mathrm{OR}=75.87 ; 95 \% \mathrm{CI}=18.42$ to $269.83 ; \mathrm{p}<0.001)$, and husband support $(\mathrm{OR}=12.85 ; 95 \% \mathrm{CI}=4.25$ to 38.86 ; $\mathrm{p}<0.001)$.

Conclusion: The use of FP implant among women in reproductive age increase with age, high education, good knowledge, information from a health worker, and husband support.
\end{abstract}

Keywords: implant, family planning, women in reproductive age

\section{Correspondence:}

Dionesia Octaviani Laput. Masters Program in Public Health, Faculty of Public Health, Universitas Nusa Cendana, Kupang, East Nusa Tenggara. Email: dinnylaput9@gmail.com. Mobile: 085228277547. 